\title{
Aortic regurgitation and aortic valve replacement during repair of acute aortic dissection
}

\author{
T Yamamoto*, T Takano, T Terasaki, Y Wada, T Seto, J Amano \\ From 23rd World Congress of the World Society of Cardio-Thoracic Surgeons \\ Split, Croatia. 12-15 September 2013
}

\section{Background}

It is still on debate whether an aortic valve should be preserved or repaired or replaced during surgery for $A A D$ although aortic regurgitation (AR) with acute aortic dissection (AAD) is recently treated with valve-sparing root repair.

\section{Methods}

This study included 51 patients who had AR more than degree II before operation out of 271 patients who underwent surgery for AAD from January 2013 to May 2005. We performed repair of AAD without aortic valve surgery in 36 patients (group P) whereas repair with aortic valve replacement in 15 patients (group R). In-hospital mortality morbidity, mid-term mortality, major cardiovascular and neurological event was retrospectively obtained and compared between 2 groups.

\section{Results}

Age was $67 \pm 11.3$ and $57 \pm 14.7$ years old in group $R$ and $\mathrm{P}$, respectively $(\mathrm{p}=0.611)$. Preoperative mean AR degree was $2.67 \pm 0.74$ in group $P$ and $2.77 \pm 1.1$ in group $R(p=$ 0.735). Mean follow-up in group $P$ was $20.9 \pm 19.3$ months and was $35.6 \pm 26.9$ months in group $R$.

In-hospital mortality occurred in each patient of group $\mathrm{P}$ and $\mathrm{R}(\mathrm{p}=0.814)$. Cardiopulmonary bypass time was significantly shorter at $297 \pm 72.0 \mathrm{~min}$ in group $\mathrm{P}$ than group $\mathrm{R}$ of $424 \pm 145.6 \mathrm{~min}(\mathrm{p}=0.004)$. Postoperative complications occurred in $11.1 \%$ of group P, 33\% of group $\mathrm{R}(\mathrm{p}=$ 0.058 ). Late death was $8.5 \%$ in group $P$, and $14 \%$ in group $\mathrm{R}(\mathrm{p}=0.55)$. Cerebrovascular events occurred in $2.9 \%$ of group $P$, and $13.3 \%$ of group $R(p=0.192)$. Cardiovascular event was observed in $5.7 \%$ of group P, and in $14.3 \%$ of group $R(p=0.567)$. In group $P, A R$ was decreased to

* Correspondence: yamamotota@shinshu-u.ac.jp

Department of Cardiovascular Surgery, Shinshu University School of Medicine, Matsumoto, Japan
0.77 degree immediately after the surgery and maintained at 1.16 degree 20.9 months after the surgery. No patient received aortic valve surgery in group $\mathrm{P}$ during follow-up although one patient required re-valve replacement in group R.

\section{Conclusion}

AAD repair without aortic valve replacement could be applicable when the patients presented with II -III degree of AR to reduce operation time and possible morbidity.

Published: 11 September 2013

doi:10.1186/1749-8090-8-S1-044

Cite this article as: Yamamoto et al:: Aortic regurgitation and aortic valve replacement during repair of acute aortic dissection. Journal of Cardiothoracic Surgery 2013 8(Suppl 1):O44.

Submit your next manuscript to BioMed Central and take full advantage of:

- Convenient online submission

- Thorough peer review

- No space constraints or color figure charges

- Immediate publication on acceptance

- Inclusion in PubMed, CAS, Scopus and Google Scholar

- Research which is freely available for redistribution 